\title{
Invasive Plants in Natural Areas: Air Potato (Dioscorea bulbifera) ${ }^{1}$
}

\author{
Stephen F. Enloe and Ken Langeland ${ }^{2}$
}

\section{Introduction}

Plants provide us with food and fiber, decorate our yards and gardens, and provide habitat for wildlife. However, when plants grow where they are not wanted, we call them weeds. To homeowners, weeds may be unwanted plants in lawns or gardens. To farmers, weeds are plants that interfere with raising crops or livestock. To biologists who manage natural areas, weeds are plants that interfere with the functions of natural communities.

Natural area weeds are often introduced plant species (a species brought to a new geographic area intentionally or unintentionally by humans) that have become established (a self-sustaining and reproducing population in a specified geographic area without the need for human intervention). When these species cause harm to humans or the environment, they are referred to as invasive species. Invasive plants are weeds that alter the functions and value of natural areas by outcompeting native species and disrupting ecosystem services. Air potato can do this by forming dense cover that blankets native vegetation, eventually displacing it. Natural area managers should remove invasive plant species such as air potato to maintain the integrity of natural areas.
Air potato (Dioscorea bulbifera) has been recognized as a serious invasive plant species in Florida since the early 1990s. It was listed as a Category 1 invasive plant in 1993 by the Florida Invasive Species Council and was subsequently added to the Florida Noxious Weed List by the Florida Department of Agriculture and Consumer Services in 1999 (5b-57.007 FAC). Plants on the Florida Noxious Weed List may not be introduced, possessed, moved, or released without a permit.

\section{Impacts}

Air potato can quickly engulf native vegetation in natural areas, climbing high into mature tree canopies (Figure 1). It produces large numbers of bulbils (aerial tubers), which facilitate its spread and make it extremely difficult to eliminate because new plants sprout from even very small bulbils. It invades a variety of habitats, including pinelands and hammocks of natural areas (Langeland et al. 2008). Air potato also thrives in urban forests, where habitat fragmentation and introduction as a novel horticultural species have facilitated its invasion.

1. This document is SS AGR 164, one of a series of the Agronomy Department, UF/IFAS Extension. Original publication date May 2001. Revised March 2008, December 2017, and December 2021. Visit the EDIS website at https://edis.ifas.ufl.edu for the currently supported version of this publication.

2. Stephen F. Enloe, professor; and Ken Langeland, professor emeritus, Agronomy Department, UF/IFAS Center for Aquatic and Invasive Plants; UF/IFAS Extension, Gainesville, FL 32611. M. J. Meisenburg contributed to the original publication.

The use of trade names in this publication is solely for the purpose of providing specific information. UF/IFAS does not guarantee or warranty the products named, and references to them in this publication do not signify our approval to the exclusion of other products of suitable composition.

All chemicals should be used in accordance with directions on the manufacturer's label.

The Institute of Food and Agricultural Sciences (IFAS) is an Equal Opportunity Institution authorized to provide research, educational information and other services

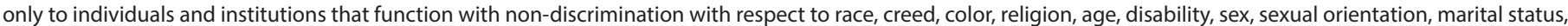

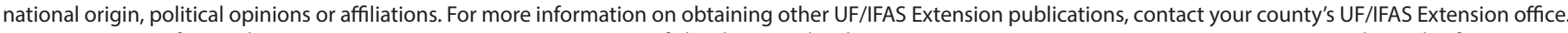
U.S. Department of Agriculture, UF/IFAS Extension Service, University of Florida, IFAS, Florida A \& M University Cooperative Extension Program, and Boards of County Commissioners Cooperating. Andra Johnson, dean for UF/IFAS Extension. 


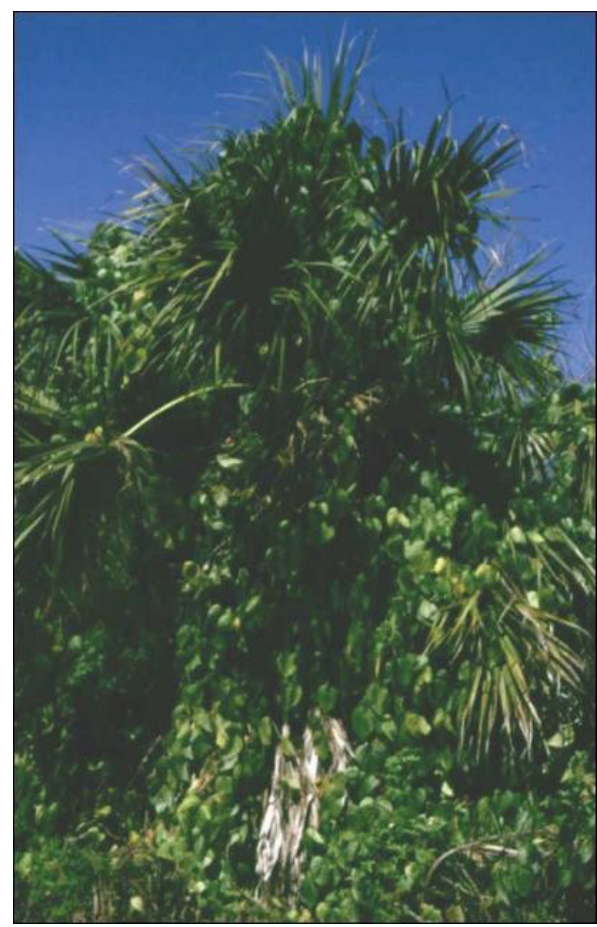

Figure 1. Air potato vine engulfing native cabbage palm. Credits: Ken Langeland, UF/IFAS

\section{Distribution}

Native to tropical Asia and sub-Saharan Africa, air potato was spread by ancient Polynesians throughout much of the South Pacific where it is now considered invasive. It was brought to the Americas from Africa during the slave trade (Coursey 1967) and introduced to Florida in 1905 (Morton 1976). It is found throughout the state from Escambia County in the Panhandle to the Florida Keys (Dioscorea bulbifera - Species Page - ISB: Atlas of Florida Plants (usf. edu)).

Air potato is a member of the yam family (Dioscoreaceae). Yams are cultivated for their edible underground tubers in western Africa, where they are important commodities. However, uncultivated species such as air potato are generally bitter or even poisonous.

\section{How to Recognize Air Potato}

Air potato is a vigorously twining herbaceous vine, often arising from an underground tuber. Freely branching stems grow to $60 \mathrm{ft}$ in length. Stems are round or slightly angled in cross-section and twine to the left (counterclockwise). Aerial tubers (bulbils) freely form in leaf axils (Figure 2). Bulbils are usually roundish with mostly smooth surfaces. They grow up to 5 in $x 4$ in (Figure 2). Leaves are long petioled (stalked) and alternate. Blades grow to 8 in or more in length and are broadly heart shaped, with basal lobes that are usually rounded as well as arching veins all originating from one point (Figures 3 and 4). Flowers are rare (in Florida), small, and fragrant, with male and female flowers arising from leaf axils on separate plants (i.e., a dioecious species) in panicles or spikes up to 4 in long (Figure 4). To date, only female plants have been found in Florida. Fruit is a capsule; seeds are partially winged.

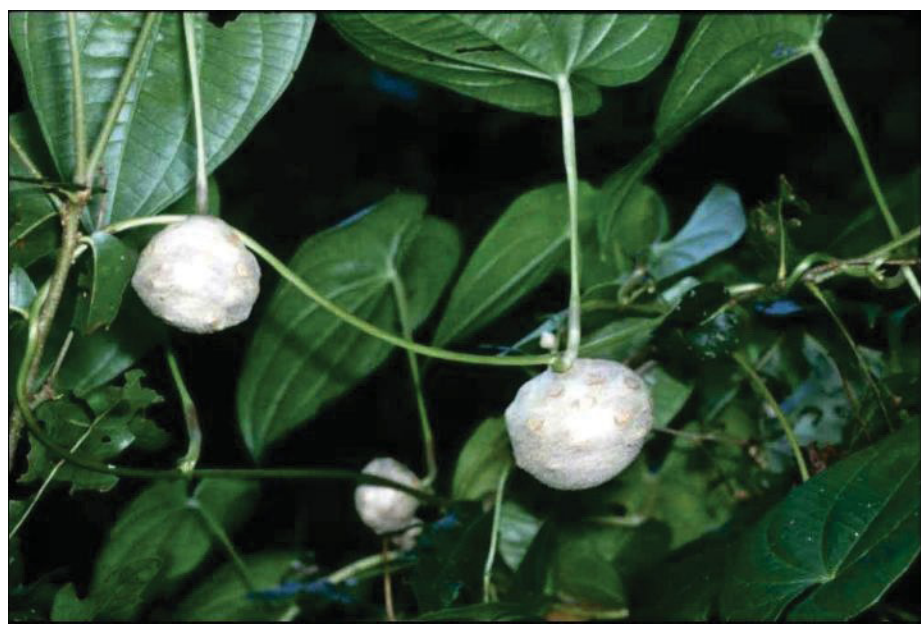

Figure 2. Air potato bulbils form in leaf axils. Credits: Ken Langeland, UF/IFAS

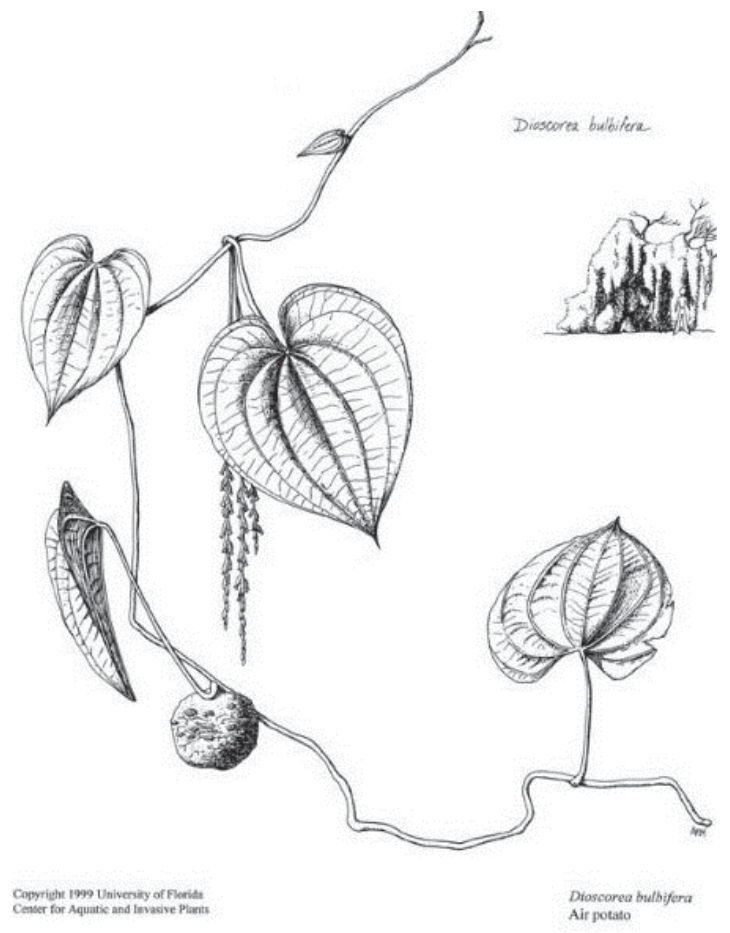

Figure 3. Air potato (Dioscorea bulbifera).

Credits: UF/IFAS Center for Aquatic and Invasive Plants

Winged yam (Dioscorea alata), often mistaken for air potato, is similar in appearance and is also an invasive species. Climbing up to $80 \mathrm{ft}$ in length, stems are square in cross-section with "winged" corners that are often tinged with red or purple. These stems twine to the right (clockwise). Winged yam has opposite leaves that are more triangular and larger than those of air potato. Figure 5 
shows air potato and winged yam growing alongside each other. Although not as abundant as air potato, winged yam nonetheless ranges from Escambia to Miami-Dade Counties (Dioscorea alata - Species Page - ISB: Atlas of Florida Plants (usf.edu)) and is likely now more prevalent than previously thought. Winged yam can produce massive edible tubers (Figure 6), some of which have been recorded to weigh over 100 pounds.

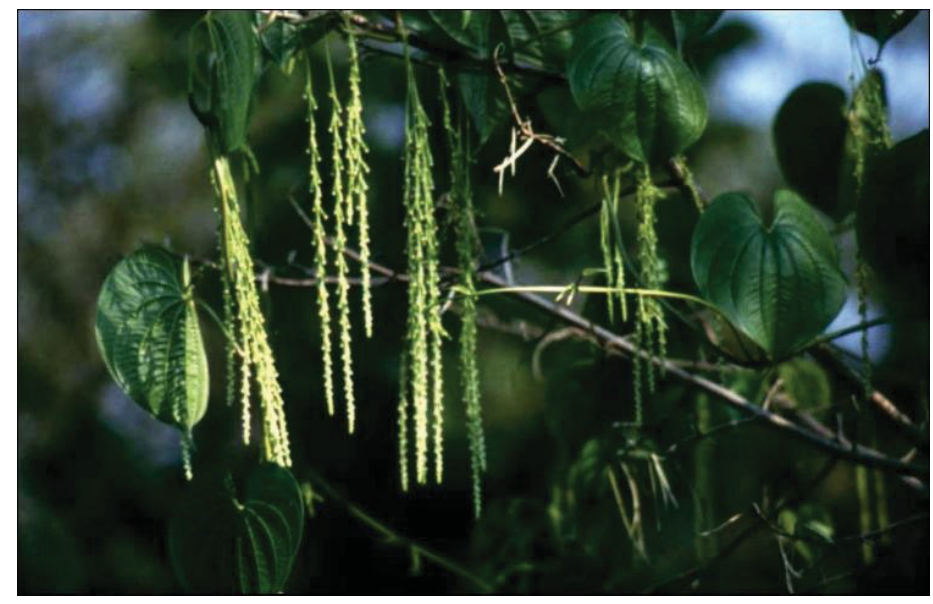

Figure 4. Air potato flowers.

Credits: Ken Langeland, UF/IFAS

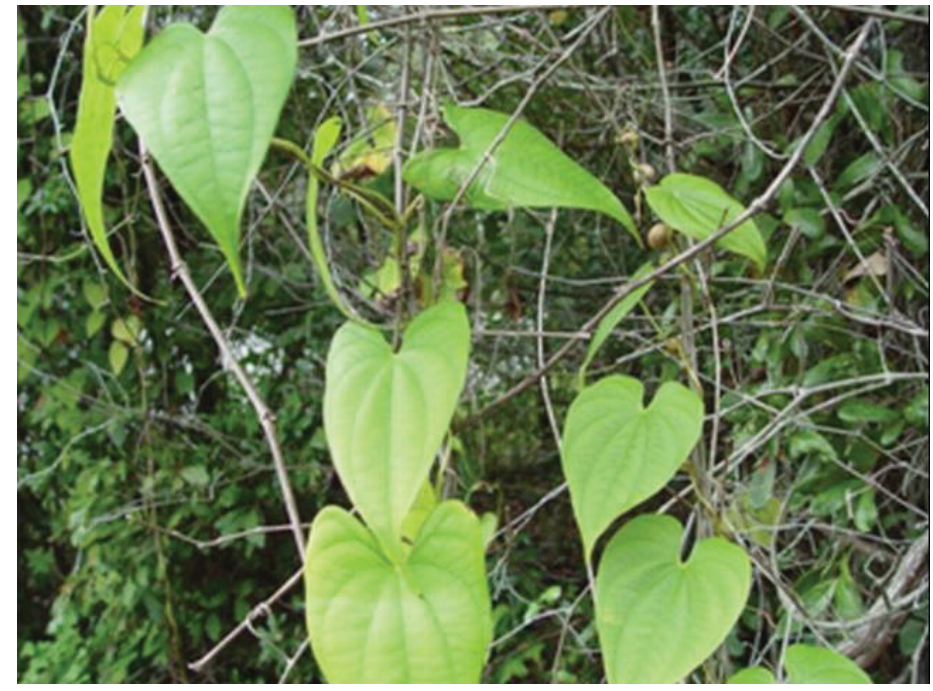

Figure 5. Side-by-side comparison of winged yam (left) and air potato (right).

Credits: Michael Meisenburg, UF/IFAS

Three other introduced species of Dioscorea may be encountered in Florida: Chinese yam (D. polystachya, high invasion risk), Zanzibar yam (D. sansibarensis, high invasion risk), and ornamental yam (D. dodecaneura, unknown invasion risk). Our native wild yams (D. villosa and $D$. floridana) are infrequent in hammocks and floodplains of northern and western Florida; these never form aerial tubers and have leaf blades that rarely reach 6 in long.

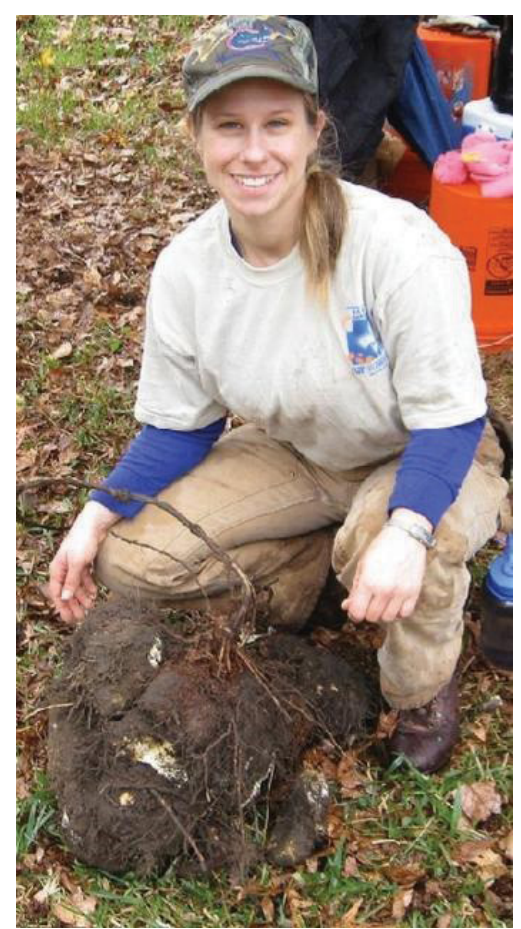

Figure 6. Underground tuber of winged yam. Credits: Wendy Wilbur, UF/IFAS

\section{Controlling Air Potato in Florida}

For many years, air potato has been manually controlled by cutting climbing vines, digging the tubers (Figure 6), and collecting and destroying the bulbils produced in the leaf axils (Figure 7). As many bulbils as possible must be removed from infested sites (Figure 7). Remaining bulbils will produce new vines. All plant material, including bulbils, must be disposed of in such a way that they do not spread the vines to new areas (for example, in a landfill or where they will be incinerated). Plants become dormant in winter (during short day-length). Locating and removing bulbils is easier during winter months when air potato and other vegetation are not as dense. Air potato bulbils cannot tolerate freezing, and placing them overnight in a freezer is the best way to prevent them from starting new infestations. On a larger scale, coordinated bulbil collection events, such as Gainesville's Air Potato Roundup (now called the Great Invader Raider Rally), have resulted in the collection of thousands of pounds of bulbils. These types of volunteer events have been very useful for increasing public knowledge of invasive plant issues and in controlling air potato in many city parks. However, a biological control method for air potato has greatly reduced the need for volunteer efforts in many situations.

The air potato leaf beetle, Lilioceris cheni Gressit \& Kimoto (Coleoptera: Chrysomelidae), native to Nepal and China, was first released in Florida in 2011 (Figure 8). The insect is specific to air potato and does not harm native plants. 
The air potato leaf beetle feeds on the leaves and causes a skeleton-like appearance (Figure 8). The damage can be so severe that aerial bulbil production, climbing ability, and competitive nature of air potato are all greatly reduced. The insect does not eradicate air potato, but the damage it inflicts makes this insect a growing success story for biological control in Florida. For more information on the biology and ecology of the air potato leaf beetle, see EDIS publication EENY-547, Air Potato Leaf Beetle (Suggested Common Name), Lilioceris cheni Gressitt and Kimoto (Insecta: Coleoptera: Chrysomelidae: Criocerinae) (https://edis. ifas.ufl.edu/in972). The insect has been widely distributed throughout Florida at thousands of release sites. Currently, availability of the insect for continued distribution is handled by FDACS (https://www.fdacs.gov/AgricultureIndustry/Pests-and-Diseases/Plant-Pests-and-Diseases/ Biological-Control/Air-Potato-Vine-Biological-Control) because the UF/IFAS redistribution program ended in 2019.

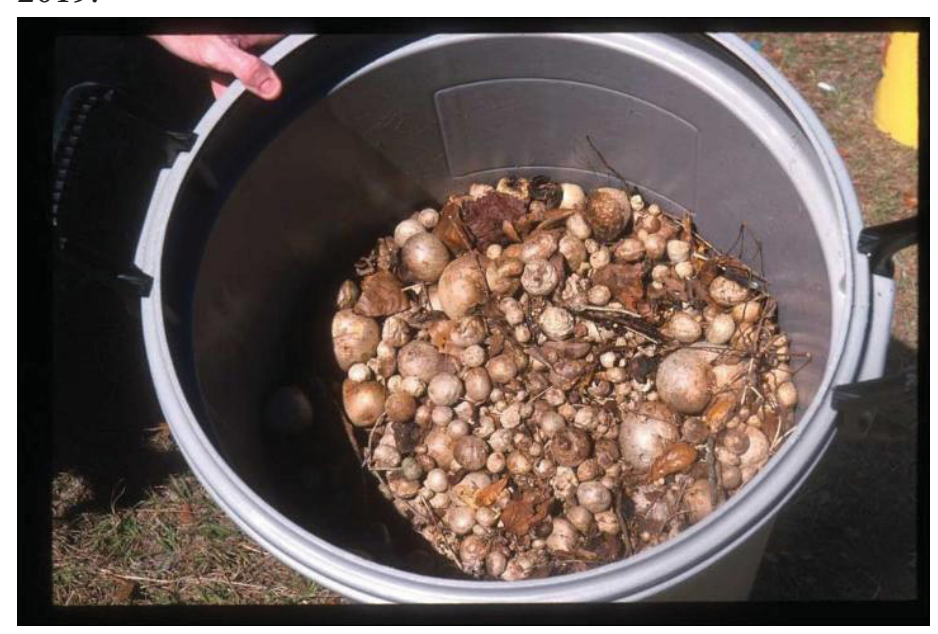

Figure 7. Remove air potato bulbils and other plant material from the site and dispose of in such a way that they do not spread the vines to new areas.

Credits: Ken Langeland, UF/IFAS

For areas where the air potato leaf beetle has not successfully established, the herbicide glyphosate can be used for air potato control. Glyphosate is effective for foliar applications but does not kill aerial bulbils that have already been produced. The high climbing growth also makes foliar treatment difficult for applicators, and only partial control is achieved. Additionally, glyphosate is not effective in completely killing the underground tubers, which resprout following foliar treatment. This generally results in the need for multiple treatments. The optimal treatment timing is in the late summer and fall when downward translocation of the herbicide to the roots and tubers is maximized. However, air potato is susceptible to frost, and poor control is likely if plants experience a cold period just before or shortly after treatment.

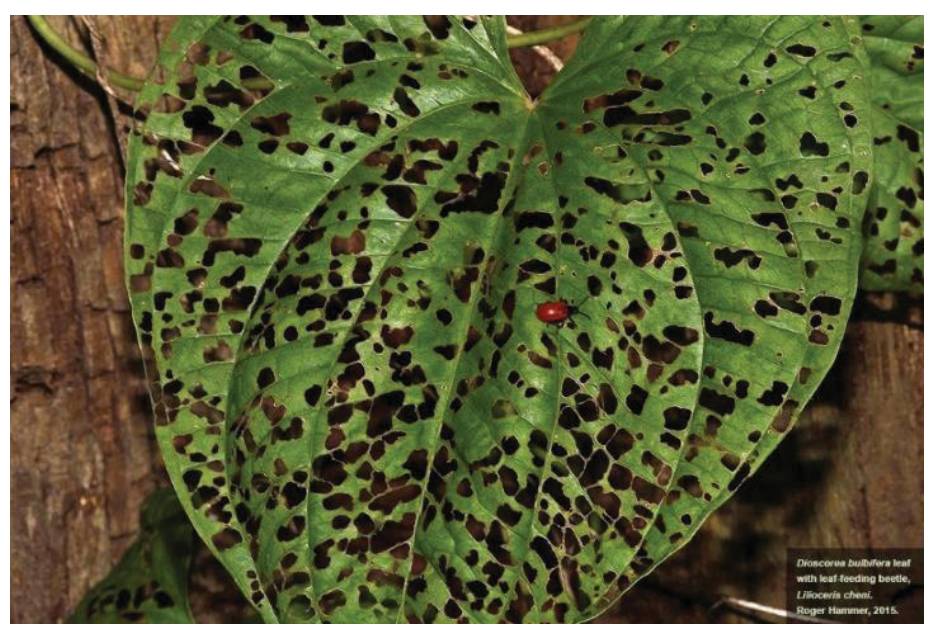

Figure 8. Dioscorea bulbifera leaf damage by the air potato leaf beetle, Lilioceris cheni.

Credits: Roger Hammer

\section{References}

Coursey, D. G. 1967. Yams: An Account of the Nature, Origins, Cultivation, and Utilization of the Useful Members of Dioscoreaceae. London: Longmans, Green and Co. Ltd.

Langeland, K. L., H. M. Cherry, C. M. McCormick, and K. A. Craddock Burks. In press. Identification and Biology of Non-Native Plants in Florida's Natural Areas, $2^{\text {nd }}$ edition. SP 257. Gainesville: University of Florida Institute of Food and Agricultural Sciences. http://plants.ifas.ufl.edu/node/613

Morton, J. F. 1976. "Pestiferous Spread of Many Ornamental and Fruit Species in South Florida." Proc. Fla. State Hort. Soc. 89:348-353. 